\title{
Особливості ендоскопічного гемостазу при виразкових гастродуоденальних кровотечах у хворих на цукровий діабет 2 типу
}

\author{
P. D. FOMIN, H. V. HULA \\ National Medical University by O. O. Bohomolets
}

\author{
ENDOSCOPIC HEMOSTASIS SPECIFIC FEATURES AT ULCEROUS GASTRODUODENAL BLEEDINGS IN \\ PATIENTS WITH TYPE 2 DIABETES MELLITUS
}

\begin{abstract}
Проаналізовано результати лікування 133 хворих із виразковими гастродуоденальними кровотечами (ВГДК) за період 2000-2004 pp., 3 них 81 хворий на цукровий діабет 2 типу (ЦД). Встановлено, що для хворих на ЦД із нестабільним гемостазом (НГ) у виразці були характерними більша частка паціснтів із тяжким ступенем ІІКК $(55,1$ проти 36,4 \% хворих із НГ контрольної групи; р<0,05). У хворих на ЦД при ВГДК помірного та середнього ступенів виявляли переважно стигмати F IIa $(p<0,05)$, а при тяжкому ступені крововтрати - F IIb $(p<0,05)$, водночас був максимальним відсоток F I $(p<0,05)$. Застосування ЕГ у 52,3 \% хворих на ЦД 3 ендоскопічними стигматами триваючої кровотечі та нестабільного гемостазу дозволило зупинити кровотечу, провести профілактику її рецидиву й уникнути невідкладної операції.

We investigated the results of treatment of 133 patients with ulcerous gastroduodenal bleeding (UGDB) for the period 2000-2004, 81 of them has 2 type diabetes mellitus (DM). It was found out that diabetic patients with unstable hemostasis (UH) in the ulcer were characterized by higher proportion of patients with severe gastrointestinal $(55.1 \%$ vs. $\mathbf{3 6 . 4} \%$ of patients with $\mathrm{UH}$ control group, $\mathrm{p}<\mathbf{0 . 0 5})$. In diabetic patients with moderate and medium UGDB showed mainly stigmata F IIa $(p<0.05)$, with severe UGDB - F IIa $(p<0.05)$, while the highest percentage was F I $(\mathrm{p}<\mathbf{0 . 0 5})$. The use of EG in $\mathbf{5 2 . 3} \%$ of diabetic patients with high-risk lesion (endoscopic stigmata of active bleeding, adherent clot or non-bleeding visible vessel) allowed to stop the bleeding, to prevent its recurrence and to avoid urgent surgery.
\end{abstract}

Постановка проблеми і аналіз останніх досліджень та публікацій. Незважаючи на потужний прогрес світової медицини у консервативному та хірургічному лікуванні виразкової хвороби (ВX) шлунка і дванадцятипалої кишки (ДПК), виразкові гастродуоденальні кровотечі (ВГДК) продовжують посідати чільне місце у структурі гострої хірургічної патології, водночас супроводжуючись значним рівнем летальності $[1,3,5,7]$. ВГДК $€$ одним із найчастіших невідкладних станів у практиці хірургів та ендоскопістів [1, 3, 5-8].

На даний час у розвинених країнах відзначено зростання частоти ВГДК на фоні старіння населення, наростання множинної супутньої хронічної патології, пандемічного збільшення числа хворих на цукровий діабет (ЦД) 2 типу [2, 6-10]. За даними окремих дослідників, ЦД є чинником ризику кровотечі при ВХ, частота ВГДК у хворих на ЦД сягає $10 \%$, а летальність - 16,6\% [10].

Поряд із наявністю численних досліджень та детально розроблених настанов щодо ендоскопіч- ної діагностики і лікування ВГДК із різними варіантами ендоскопічного гемостазу, прогнозу рецидиву кровотечі, обгрунтуванням вибору лікувальної тактики, а також - достатньо вивченим питанням функціональних та патоморфологічних змін при ВХ шлунка і ДПК у хворих на ЦД, результати лікування ВГДК у хворих на ЦД далекі від очікуваних $[1,3,5-7]$. Роботи з вивчення ендоскопічних особливостей ВГДК при ЦД поодинокі, особливості ендоскопічного гемостазу висвітлені недостатньо [2, 8-10].

Оцінка надійності гемостазу та ризику рецидиву кровотечі у хворих на ЦД при ВГДК є вирішальною. Поряд з необхідністю термінового виконання езофагогастродуоденоскопії (ЕГДС) у випадку нестабільного гемостазу (НГ) потрібне застосування малоінвазивного ендоскопічного втручання (MEB) на кровоточивій виразці, проведення ендоскопічного моніторингу, що дає змогу дещо зменшити потребу ургентного операційного втручання $[2,7,10]$. Вивчення особливостей НГ при ВГДК у 
хворих на ЦД допоможе покращити якість лікування хворих на ЦД із ВГДК, зменшити рівень летальності, підвищити економічну ефективність стаціонарної медичної допомоги.

Мета роботи: вивчити ендоскопічні особливості гострокровоточивих гастродуоденальних виразок із нестабільним гемостазом у хворих на цукровий діабет, госпіталізованих за період 20002004 pp. у Київський міський центр із надання допомоги хворим на шлунково-кишкові кровотечі.

Матеріали і методи. Проаналізовано результати ендоскопічних обстежень 133 хворих на ВГДК, серед яких -81 хворий на ЦД 2 типу (основна група) і 52 - без ЦД (контрольна група). Середній вік хворих основної групи склав $(66,9 \pm 9,3)$ року, переважали чоловіки $(56,8 \%)$, середній ліжко-день $(10,3 \pm 6,8)$ доби. Час від моменту появи симптомів ШКК складав від 1,5 год до 14 діб (у середньому $(2,7 \pm 0,7)$ доби).

Ступінь тяжкості та компенсації ЦД визначали згідно з рекомендаціями ВООЗ (1999), оцінку ступеня тяжкості шлунково-кишкової кровотечі (ШКК) проводили за класифікацією В. Д. Братуся [1]. Переважали хворі на субкомпенсований ЦД середньої тяжкості (39,5 \%), із ШКК тяжкого ступеня (40,7 \%) на тлі субкомпенсованого ЦД $(23,5$ \%).

Езофагогастродуоденоскопію проводили фіброгастродуоденоскопами Olympus GIF 1T, GIF Q20,
GIF Q40. У перші 3 год від моменту госпіталізації ЕГДС проведено у 90,1 \% хворих, у відстрочений період $((1,3 \pm 0,3)$ доби $)$ - у 9,9 \% у зв'язку із тяжким станом при госпіталізації та необхідністю невідкладної інтенсивної терапії.

Стигмати гемостазу при ЕГДС оцінювали за класифікацією J. Forrest у модифікації В. I. Нікішаєва [5]. Об'єктом дослідження були хворі з нестабільним гемостазом (НГ) у кровоточивій виразці, а саме - у випадку триваючої кровотечі (F I), великої тромбованої судини (F IІа), фіксованого згортка (F IIb). Ознаки НГ виявлено у 49 хворих на ЦД $(60,5 \%)$, зокрема - у 34,6 \% на ЦД середньої тяжкості (табл. 1).

Середній вік хворих на ЦД з ознаками НГ склав $(66,3 \pm 9,5)$ року, середній ліжко-день - $(11,2 \pm 7,8)$ доби. Тяжкий ступінь крововтрати констатовано у 55,1 \% хворих на ЦД із НГ у виразці. У випадку крововтрати помірного та середнього ступеня виявляли переважно велику тромбовану судину $(26,5 \%)$, а при тяжкому ступені ШКК - кровоточиві виразки з фіксованими згортками $(30,6 \%)$, водночас був максимальним відсоток триваючих кровотеч (табл. 2).

Серед 49 хворих на ЦД із стигматами НГ джерелом ШКК у 40 (81,6 \%) була виразка ДПК, у 9 $(18,4 \%)$ - виразка шлунка, з них із локалізацією в тілі шлунка - у 1 (2\%), антральному відділі - у 3 (6,1 \%), препілоричному відділі - у 4 (8,2 \%), пілорусі - у 1 (2 \%) (табл. 3).

Таблиця 1. Розподіл хворих на ЦД із ВГДК залежно від форми ЦД та стигмат кровотечі

\begin{tabular}{|l|c|c|c|c||}
\hline $\begin{array}{c}\text { Групи стигмат кровотечі } \\
\text { хворих на ЦД З ВГДК }\end{array}$ & $\begin{array}{c}\text { ЦЛ 2 типу, легкий } \\
\text { перебіг }\end{array}$ & $\begin{array}{c}\text { ИД 2 типу, середньої } \\
\text { тяжкості }\end{array}$ & $\begin{array}{c}\text { ЦД 2 типу, тяжкий } \\
\text { перебіг }\end{array}$ & Разом \\
\hline Хворих на ЦД з ВГДК & 19 & 50 & 12 & 81 \\
\hline Групи стигмат ШКК, \% & & & & \\
\hline F Ia & - & 1,2 & - & 1,2 \\
\hline F Ib & - & $4,9^{*}$ & $1,2^{*}$ & 6,2 \\
\hline F Ix & - & 1,2 & - & 1,2 \\
\hline F IIa & 7,4 & $14,8^{*}$ & $2,5^{*}$ & 24,7 \\
\hline F IIb & $6,2^{*}$ & $12,4^{*}$ & 8,6 & 27,2 \\
\hline F IIc & - & 9,9 & 1,2 & 11,1 \\
\hline F III & 9,9 & $17,3^{*}$ & $1,2^{*}$ & 28,4 \\
\hline
\end{tabular}

Примітка. $*-p<0,05$.

Таблиця 2. Розподіл хворих на ЦД залежно від стигмат ШКК та тяжкості крововтрати (за класифікацією В. Д. Братуся)

\begin{tabular}{||c|c|c|c|c|c|c||}
\hline \multirow{2}{*}{ Ступінь крововтрати } & \multicolumn{7}{|c||}{ Групи стигмат ШКК } & \multirow{2}{*}{ Bcix, \% } \\
\cline { 2 - 7 } & F Ia & F Ib & F Ix & F IIa & F IIb & \\
\hline Помірний & - & - & - & $12,2^{*}$ & $8,2^{*}$ & 20,4 \\
\hline Середній & 2,0 & 2,0 & 0,0 & $14,3^{*}$ & $6,1^{*}$ & 24,5 \\
\hline Тяжкий & - & $8,2^{*}$ & 2,0 & $14,3^{*}$ & $30,6^{*}$ & 55,1 \\
\hline \hline
\end{tabular}

Примітка. * $-\mathrm{p}<0,05$. 
Таблиця 3. Розподіл Хворих на ЦД за локалізацією та розмірами кровоточивої виразки шлунка та ДПК залежно від стигмат ШКК

\begin{tabular}{|c|c|c|c|c|c|c|}
\hline \multirow{2}{*}{$\begin{array}{c}\text { Кількість хворих з НГ, діаметр } \\
\text { виразки шлунка та ДПК }\end{array}$} & \multicolumn{5}{|c|}{ Г Групи стигмат ШКК } & \multirow{2}{*}{ Bcix, \% } \\
\hline & F Ia & F Ib & F Ix & F IIa & $\mathrm{F} \mathrm{IIb}$ & \\
\hline Кількість хворих з НГ & 1 & 5 & 1 & 20 & 22 & 49 \\
\hline \% від кількості хворих із НГ & $2,0^{*}$ & 10,2 & 2,0 & $40,8^{*}$ & $44,9^{*}$ & \\
\hline \multicolumn{7}{|l|}{ Джерело кровотечі, діаметр виразки } \\
\hline виразка шлунка, \% & 2,0 & 2,0 & 2,0 & 8,2 & 4,1 & 18,4 \\
\hline $0,5-0,9 \mathrm{~cm}$ & - & - & 2,0 & 4,1 & 2,0 & 8,2 \\
\hline $1-1,9 \mathrm{~cm}$ & 2,0 & - & - & - & - & 2,0 \\
\hline $2-4 \mathrm{~cm}$ & - & 2,0 & - & 4,1 & 2,0 & 8,2 \\
\hline виразка ДПК, \% & - & 8,2 & - & 32,7 & 40,8 & 81,6 \\
\hline $0,3-0,9 \mathrm{~cm}$ & - & 2,0 & - & 10,2 & 12,2 & 24,4 \\
\hline $1-1,9 \mathrm{~cm}$ & - & 4,1 & - & 20,4 & 18,4 & 42,9 \\
\hline $2-4 \mathrm{~cm}$ & - & 2,0 & - & 2,0 & 10,2 & 14,3 \\
\hline
\end{tabular}

Примітка. $*-p<0,05$.

Глибина кровоточивої виразки у 63 \% хворих на ЦД із НГ становила 0,3 см та більше. Стигмати ШКК підгрупи F IIb частіше відзначали у випадку глибини виразки понад 0,3 см порівняно з підгрупою F IIа, коли вона найчастіше становила до 0,3 cм (табл. 4).

Більшість кровоточивих виразок ДПК із НГ (57,5 \%) локалізувалася по задній стінці цибулини ДПК, яка є критичною зоною з високим ризиком розвитку кровотечі та іiї рецидиву (табл. 5).

Виявлені при ЕГДС стигмати НГ були показанням до застосування методів MEВ із метою зупинки активної кровотечі, профілактики ії рецидиву у підгрупах F IIa та F IIb. У 75,5 \% хворих із НГ застосовано один із методів МЕВ - хімічну коагуляцію кровоточивого субстрату препаратом "Кап- рофер" [4]. Не застосовано МЕВ у 24,5 \% хворих підгруп F IIa (18,4 \%) та F IIb (6,1%). У 4 (8,2 \%) пацієнтів з активною кровотечею МЕВ був ефективним. Ендоскопічний моніторинг через 6-24 год після первинної ЕГДС та застосування МЕВ проведено у $51 \%$ хворих із НГ. У 1 хворого підгрупи F IIb на тлі тяжкого субкомпенсованого ЦД на 13ту добу лікування відбувся рецидив кровотечі з виразки задньої стінки ДПК діаметром 2,5 см, глибиною 0,5 см. Було проведено повторне МЕВ, кровотечу зупинено.

Операційне втручання виконано 5 хворим на ЦД iз НГ із кровоточивою виразкою ДПК $(10,2 \%)$. Показаннями до втручання у 3 хворих $(6,1 \%)$ послужили триваюча кровотеча та неефективність MEB, у 2 хворих (4,1 \%) - високий ризик рецидиву

Таблиця 4. Розподіл хворих на ЦД із ВГДК із стигматами НГ залежно від глибини кровоточивої виразки, \%

\begin{tabular}{||c|c|c|c|c|c|c||}
\hline \multirow{2}{*}{ Глибина виразки } & \multicolumn{5}{c||}{ Групи стигмат ШКК } & \multirow{2}{*}{ Bcix, \% } \\
\cline { 2 - 7 } & F Ia & F Ib & F Ix & F IIa & F IIb & \\
\hline $0,05-0,2$ см (поверхневі, неглибокі) & 2,0 & 2,0 & 2,0 & $18,4^{*}$ & $10,2^{*}$ & 34,7 \\
\hline 0,3 см (глибокі) & - & 4,1 & - & 12,2 & 14,3 & 30,6 \\
\hline Понад 0,3 см (значної глибини) & - & 4,1 & - & $10,2^{*}$ & $20,4^{*}$ & 34,7 \\
\hline \hline
\end{tabular}

$\overline{\text { Примітка. } *-\mathrm{p}<0,05 \text {. }}$

Таблиця 5. Розподіл хворих на ЦД залежно від розташування кровоточивої виразки у цибулині ДПК та стигмат НГ, \%

\begin{tabular}{|c|c|c|c|c|c|c|}
\hline \multirow{2}{*}{ Стінка цибулини ДПК } & \multicolumn{5}{|c|}{ Групи стигмат ШКК } & \multirow{2}{*}{ Bcix, \% } \\
\hline & F Ia & $\mathrm{F} \mathrm{Ib}$ & F Ix & F IIa & $\mathrm{F} \mathrm{IIb}$ & \\
\hline Разом, \% & - & 10,0 & - & 40,0 & 50,0 & \\
\hline Передня & - & - & - & 7,5 & 5,0 & 12,5 \\
\hline Верхня & - & - & - & 7,5 & 10,0 & 17,5 \\
\hline Задня & - & 10,0 & - & $17,5^{*}$ & $30,0 *$ & 57,5 \\
\hline Нижня & - & - & - & 7,5 & 5,0 & 12,5 \\
\hline
\end{tabular}

$\overline{\text { Примітка. } *-\mathrm{p}<0,05 .}$ 
ВГДК при значних розмірах виразки (ступінь гемостазу F 2a, F 2 b при діаметрі виразки, відповідно, 1 та 1,5 см, глибині 0,3 та 0,5 см). Післяопераційної летальності не було. Середній ліжко-день у цій підгрупі склав $(16,2 \pm 2,3)$ доби.

3 метою досягнення мети наукового дослідження складено контрольну групу із 52 хворих з ВГДК без ЦД, співмірну з основною за віком, статтю, ступенем тяжкості крововтрати, характеристиками виразкового субстрату. У групі контролю переважали чоловіки $(71,2 \%)$, середній вік - $(47,3 \pm 5,9)$ року, середній ліжко-день - $(6,3 \pm 2,2)$ доби, більшість хворих мала ШКК помірного ступеня тяжкості $(53,8 \%)$. Джерелом кровотечі були переважно виразки ДПК розмірами до 0,9 см $(88,5 \%)$. Нестабільний гемостаз констатовано у $21,2 \%$. Рецидивів кровотечі не було. Прооперовано 6 хворих (11,5\%) із ВГДК. Післяопераційної летальності не було. Загальна летальність склала 3,8 \%.

Порівняння величини дисперсії у вивчених групах проводили за критерієм Фішера, порівняння середніх величин - за критерієм Стьюдента. Розрахунки проводили, використовуючи спеціально розроблену програму для WINDOWS 7 у MS EXCELL-10.

Результати досліджень та їх обговорення. Частка хворих на ЦД серед усіх пацієнтів, госпіталізованих з ВГДК, була істотною $(2,8-3,8$ \%). Переважали хворі на субкомпенсований ЦД середньої тяжкості (39,5\%; p<0,05), з ШКК тяжкого ступеня (40,7 \% проти 15,4 \% контрольної групи; $\mathbf{p}<0,05)$. При ЕГДС у хворих на ЦД переважали стигмати НГ F I, F IIa, F IIb (60,5 \% проти 21,2 \% контрольної групи; $\mathbf{p}<0,05)$. Триваючу кровотечу відзначено лише у хворих із середньої тяжкості та тяжким перебігом ЦД $(8,5 \%$ усіх хворих на ЦД; $р<0,05)$. Більшість хворих на ЦД віднесено до підгруп НГ F IIа та F IIb (51,9 \% усіх хворих на ЦД; $p<0,05), 3$ них із ЦД середньої тяжкості - 27,2\% усіх хворих на ЦД. Середній вік хворих на ЦД з ознаками НГ суттєво не різнився від показника основної групи (66,3 проти 66,9 року; $>>0,1)$; середній ліжко-день мав тенденцію до зростання (10,3 проти 11,2 доби; $\mathrm{p}<0,1)$.

Для хворих на ЦД із НГ у виразці були характерними більша частка пацієнтів із тяжким ступенем ШКК (55,1 \% проти 36,4 \% хворих із НГ контрольної групи; $p<0,05)$. У хворих на ЦД при ВГДК помірного та середнього ступеня виявляли переважно стигмати F IIa $(\mathrm{p}<0,05)$, а при тяжкому ступені крововтрати - F IIb $(\mathrm{p}<0,05)$, водночас був максимальним відсоток F I $(\mathrm{p}<0,05)$. У випадку триваючої кровотечі, констатованої при не- відкладній ЕГДС, джерелом іiї у разі стигмат F Ia та F Ix були виразки шлунка (4,1 \% усіх хворих на ЦД з НГ; 28,6 \% хворих на ЦД підгрупи активної кровотечі FI; $\mathrm{p}<0,1)$, водночас стигмати F Ib припали переважно на виразки ДПК (8,2 \% усіх хворих на ЦД з НГ; 57,1 \% хворих на ЦД підгрупи F I; $\mathrm{p}<0,1)$. При ВГДК із виразок шлунка у хворих на ЦД у випадку НГ виявляли переважно стигмати F IIa (8,2 \% усіх хворих на ЦД з НГ; 44,4 \% хворих на ЦД підгрупи НГ із кровоточивою виразкою шлунка; $\mathbf{p}<0,1)$, тоді як для кровоточивих виразок ДПК виявлено співмірну частоту стигмат F IIa та F IIb $(\mathrm{p}<0,05)$ з тенденцією до переваги останньої (40,8 \% усіх хворих на ЦД з НГ; 50 \% хворих на ЦД підгрупи НГ із кровоточивою виразкою ДПК; $\mathrm{p}<0,1)$.

Для кровоточивих виразок шлунка та ДПК із НГ у хворих на ЦД, порівняно з хворими контрольної групи без ЦД, характерні більший діаметр (1 см та більше; 67,4 \% проти 36,4 \% контрольної групи; $\mathrm{p}<0,01)$, глибина $(0,3$ см та більше; $65,3 \%$ проти $27,3 \%$; $<0,01)$, частіша локалізація по задній стінці цибулини ДПК (57,5 \% проти 27,3\%; $<<0,01)$, більша частка ВГДК із джерелом у шлунку (18,4 \% проти $9,1 \% ; p<0,01)$. Діаметр виразкового дефекту не корелював із стигматами НГ, тобто - 3 калібром арозованої судини ( $>>0,1)$. Водночас, хворі зі стигматами ШКК підгрупи F IIb частіше мали виразки глибиною 0,3 см та глибші (34,7\%) порівняно 3 підгрупою F IIa (30,6 \%), де глибина виразки найчастіше становила до 0,3 см $(\mathrm{p}<0,05)$. Враховуючи аналіз даних розподілу кровоточивих виразок залежно від тяжкості ЦД, діаметра та глибини виразкового дефекту, виявлених стигмат ШКК, випливає взаємозалежність ангіопатії та ступеня арозії кровоточивої судини $(\mathrm{p}<0,05)$.

Застосування МЕВ у значного числа хворих на Ц $з$ ендоскопічними стигматами НГ $(65,3 \%)$ дозволило зупинити кровотечу, провести профілактику іï рецидиву i, таким чином, уникнути невідкладного операційного втручання, ризик виконання якого у цих хворих $є$ високим. Водночас були випадки неефективного МЕВ (10,2\%), рецидиву ШКК після MEB (2 \%) i, як результат, - вища загальна летальність (10,2 \% проти 3,8 \% контрольної групи без ЦД; $p<0,05)$. Операційне втручання виконували за суворими показаннями при неефективності MEB, а також у випадку високого ризику рецидиву кровотечі у хворих підгрупи F II. Водночас, з огляду на випадки неефективності МЕВ та рецидиву кровотечі (12,2 \%), методи ендоскопічних МЕВ потребують вдосконалення.

Проведене дослідження засвідчило необхідність подальшого вивчення ендоскопічних 
особливостей ВГДК у хворих на ЦД із нестабільним гемостазом у виразці, опрацювання відповідної ендоскопічної тактики у лікувально-діагностичному алгоритмі, що сприятиме поліпшенню результатів лікування цієї групи хворих.

Висновок. Своєчасне термінове проведення ендоскопічного дослідження у хворих на цукровий діабет із виразковою гастродуоденальною крово-

\section{СПИСОК ЛІТЕРАТУРИ}

1. Братусь В. Д. Острокровоточащие гигантские язвы желудка / В. Д. Братусь, В. М. Сидоренко, Н. М. Стець // Мат. респ. наук.-практ. конф. «Хірургічне лікування рецидивуючих гастродуоденальних виразок і їх ускладнень» (24-25 листопада 1995 р., Київ). - К. : Здоров'я, 1995. - С. 58-59.

2. Зайцев В. Т. Хирургическое лечение больных с язвенным желудочно-кишечным кровотечением и сопутствующим сахарным диабетом / В. Т. Зайцев, В. В. Бойко, Б. И. Пеев // Клін. хірургія. - 1994. - № 6. - С. 35-39.

3. Нікішаєв В. І. Діагностична і лікувальна фіброгастроскопія при шлунково-кишкових кровотечах / В. І. Нікішаєв // Матеріали ювілейної науково-практичної конференції, присвяченої 25-річчю створення Львівської міської клінічної лікарні швидкої медичної допомоги, "Сучасні аспекти невідкладної допомоги". - Львів. - 1997. - Кн. 1. - С. 144-145.

4. Фомін П. Д. Спосіб ендоскопічного лікування виразкової гастродуоденальної кровотечі / П. Д. Фомін, О. В. Ігнатов, О. А. Ананко, О. Б. Беляков-Бєльський, П. В. Іванчов, М. В. Щербина // Патент № 40924 А UА, опубл. 15.08.2001. Бюл. № 7, Ч.2. - С. 1.22 . течею, застосування малоінвазивного ендоскопічного втручання на кровоточивій виразці з ознаками нестабільного гемостазу забезпечує зупинку кровотечі, її профілактику, а також дає можливість уникнути ризикованої невідкладної операції. Ендоскопічний аспект є невід'ємною складовою лікувально-діагностичного алгоритму в тактиці ведення цієї групи хворих, водночас він потребує подальшого опрацювання та вдосконалення.

5. Еволюція тактичних підходів до вибору хірургічного лікування ускладнених форм виразкової хвороби / П. Д. Фомін, В. Д. Братусь, В. І. Нікішаєв, М. В. Щербина // Шпитальна хірургія. -2005 . - № 1. - С. 189-194.

6. Risk factors for rebleeding and death from peptic ulcer in the very elderly / L. W. Chow, P. Gertsch, R. T. Poon, F. J. Branicki // Br. J. Surg. - 1998. - Vol. 85. - № 1. - P. 121-124.

7. Holster I. L. Update on the endoscopic management of peptic ulcer bleeding / I. L. Holster, E. J. Kuipers // Curr. Gastroenterol. Rep. - 2011. - Vol. 13. - № 6. - P. 525-531.

8 . The influence of diabetes mellitus on short-term outcomes of patients with bleeding peptic ulcers / A. Murata, S. Matsuda, K. Kuwabara [et al.] // Yonsei Med. J. - 2012. - Vol. 53. - № 4. P. 701-707.

9. Tacheck I. Peptic ulcer disease in patients with diabetes mellitus / I. Tacheck, J. Bures // Vnitr. Lek. - 2011. - Vol. 57 - № 4. P. 347-50.

10. Diabetes and 30-day mortality from peptic ulcer bleeding and perforation: a Danish population-based cohort study / R. W. Thomsen, A. Riis, S. Christensen [et al.] // Diabetes Care. 2006. - Vol. 29. - № 4. - P. 805-810.

Отримано 23.01.13 